substance melting at $112-113^{\circ},[\alpha]_{\mathrm{v}}:-45.0^{\circ}$. By treating this compound with $10 \%$ alcoholic $\mathrm{KOH}, \beta$-cholesterol oxide, needles, Fp $136^{\circ}$ (not sharp), $[\alpha]_{\mathrm{b}}$ : $-10.4^{\circ}$ was obtained. By the usual method of acetylation, it gave the acetate, Fp 112-113 ${ }^{\circ},[a]_{\mathrm{D}}$ : $\pm \mathrm{O}^{\circ}$. By assuming that this is a pure $\beta$-oxide, the rupture of the oxide-ring was investigated.

When the above $\beta$-cholesterol-acetate oxide was treated with dry $\mathrm{HCl}$ gas, the compound (II) was obtained in almost quantitative yreld, but no formation of compound (I) was observed. When the acetate oxide was ruptured with glacial acetic acid, 3,5diacetoxy-6-hydroxycholestane was obtained.

In the light of these facts, it became clear that the claim that Ruzicka made of having obtained the compound (I) from $\beta$-oxide, or that the reason the present author obtained 3,6-diacetoxy-5-hydroxycholestane from the same compound was found to be due to the presence of $\alpha$-oxide, mixed with the raw material, $\beta$-oxide.

Judging from the examination of the $\mathrm{X}$-ray pictures of the powder, the substance spoken of as $\beta$-oxide is not a simple mixture of $\alpha$-oxide and $\beta$-oxide, but appears to be a molecular compound of the two substances.

\title{
On the Chromic Acid Oxidation of Typha-Sterol.
}

\author{
by \\ Jungo HatTori and Katutaro NaKamura - \\ [From the Scientific Laboratory of Ch. Takeda and Co. Ltd., Osaka.] \\ (Received, May 2 nd. 1940.)
}

When the acetate (Fp 125-126 $)$ of the sterol of typha was brominated, a dibromide, $\mathrm{Zp} 124-125^{\circ}$ was obtained. This compound was oxidized with $\mathrm{CrO}_{3}$ in glacial acetic acid, and trans-dehydroandrosteron was isolated from the neutral oxidation products. From the acidic fraction of the oxidation products, a substance, platelets, Fp $249^{\circ}$ (with decomposition) was isolated. The Fp of this substance corresponds roughly to 
that of 3-hydroxy-nor-cholenic acid ${ }^{1}$ ) literature, but in order to confirm whether this substance is 3-hydroxy-nor-cholenic acid, the authors attempted to synthesize this compound by Grignard's method.

The oily substance obtained by Grignard's reaction on methyl 3-acetoxy-cholenate (I) was acetylated to obtain 3-acetoxy-nor-cholenyl-diphenyl-carbinol (II), Fp 172$172.5^{\circ}$. When the latter substance was brominated in glacial acetic acid and benzene and then oxidized with $\mathrm{CrO}_{3}$, a substance, platelets $\mathrm{Fp} 249-250^{\circ}$ (with decomp.) was obtained. The analytical figures corresponds to those of 3-hydroxy-nor-cholenic acid (III), $\mathrm{C}_{23} \mathrm{H}_{36} \mathrm{O}_{3}$.

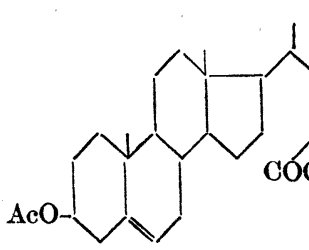

(I)

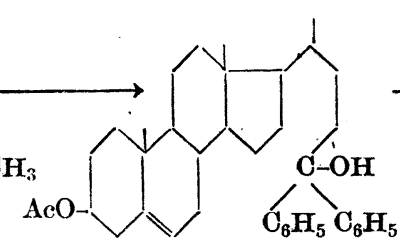

(II)

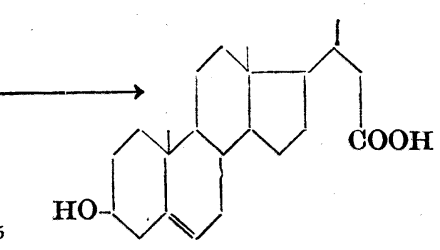

(III)

When this substance was mixed with the substance, $\left(\mathrm{Fp} 249^{\circ}\right)$ isolated from the oxidation product mentioned above, it did not give any depressed melting point, showing that these substances are identical.

The fact that the chromic acid oxidation of the sterol of typha gives 3-hydroxynor-cholenic acid, shows that this sterol belongs to the group of so-called sitosterin as already stated by Kuwada and Morimoto.2)

1) Chem. Zentr. 1937, I, 4265.

2) this Journal. 57, 62 [1937]. 
した 3-Acetoxy-5-chlor-6-oxy-cholestan とを混融しても融點降下は起らない。

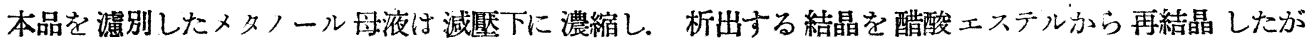

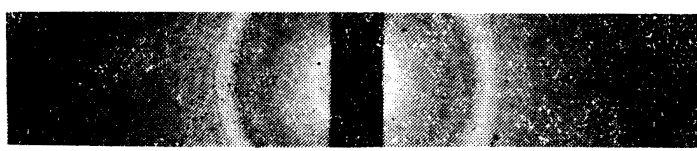

第 1 圖

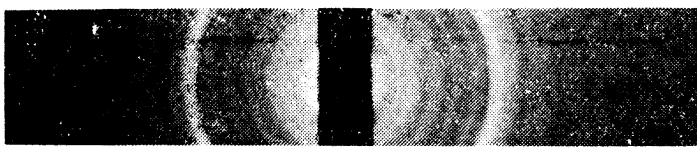

第 2 圖

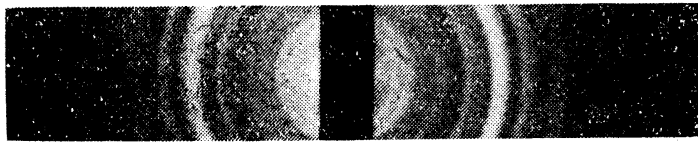

第 3 圖

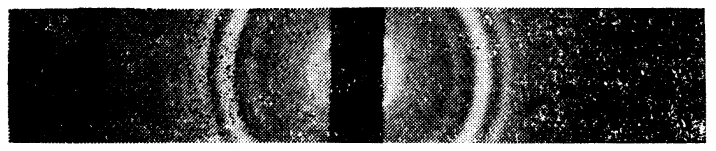

Fp 198〜200 の鱗片狀晶を得た のみであつた. 更に (V) の副成

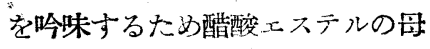
液を減區下に溜去し, 殘渣さエー テルに溶解し, 采洗, 乾燥後エー テルを溜去する・此處に得た残椬 を無水醋酸と墓沸してアセチル化 して後常法に從つて處理して, メ タフールから Fp 112〜113ㅇ太 い針狀晶壳得心. 本品と 3.6-Di一 acetoxy-5-chlor-cholestan とを混 融しても融點降下を示さない. (V)の副生は認められなかつた。

B）涾醋酸を用ひた場合 ·物 質 $1 \mathrm{~g}$ を氷醋酸 $20 \mathrm{ec}$ と共に石 綿板上て 1.5 時間煮沸後多量の水 を加へて析出する結晶を㥁別し, 之をエーテルに溶解する・エーテル層を稀 $\mathrm{NaOH}$, 水て洗涤, 乾燥後エ ーテルを溜去すると油狀物質が残留する，之を無水醋酸と煮沸後常法に從つて處理した後エーテル残渣を メタフールから再結晶して Fp 148.5〜150 の針狀晶を得た. 本品と既知の 3,5,6-Triacetoxy-cholestan と 混融しても毫も融點降下を示さない.

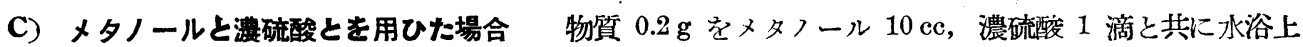
に 1.5 時聞劣沸して後前報1)に記載した如く處理して Fp 203〜204 の鱗片狀晶を得た. 3,6-Dioxy-5一 methoxy-cholestan と潉融しても融點降下を起さない.

\title{
$\mathbf{X}$ 線粉末弿上圖參照
}

\section{蒲黃ステリンのクロム酸酸化に就て}

\author{
服部順五 中村勝太郎 \\ 株式會社武田長兵衞商店研究部（昭和 15 年 5 月 2 日受理）
}

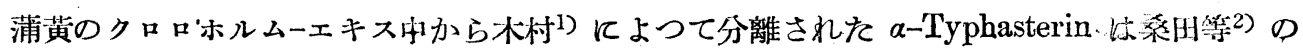
研究によると高等植物に廣く分布する Sitosterin, $\mathrm{C}_{29} \mathrm{H}_{50} \mathrm{O}$ ， と同一物質ですると云ふ。著者等

1) 本誌 50,843 [昭 5]. 2) 本誌 57, 246 [昭 12]. 
は更に之を確定するため，本品をクロム酸酸化に附し，豫期した如く 3-Oxy-nor-cholensïure を捕捉する事が出來た

桑田等の記載に從つて蒲黄のアルコールェキスから得た粗製ステリン Fp 59〜108を精製 し, 其のア七タート, Fp 125 126 $[x]_{\mathrm{D}}=-37.50^{\circ}$, を得た. 本品をブロム化してヂブロミ ド, Zp 124 125。, となし, 之を水醋酸中無水クローム酸で酸化した後常法に從つて中性物質

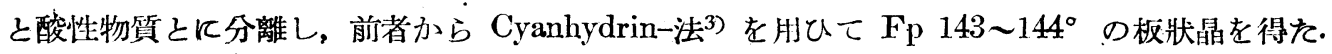
混融試驗によつて本品は trans-Dehydroandrosteron である事を確めた。次に酸性物質尔ら水 醋酸を用ひて再結晶し Fp $249^{\circ}$ (分解下) の板狀晶を得た。元素分析值永 3-Oxy-nor-cholensäure, $\mathrm{C}_{23} \mathrm{H}_{36} \mathrm{O}_{3}$, 飞一致し, 本品と 3-Oxy-cholensäure $\left(\mathrm{Zp} 238^{\circ}\right)$ とを混融すれば顯著に融點 降下を起す，更に本品が眞に期待する物質であるか否かを明にするため，著者等が管て Cholesterin の酸化によつて得た 3-Oxy-tholensäure から 3-Oxy-nor-cholensäure 尚合成して其 の異同を決定しやうう試みた。

藤井等4) は 3-Oxy-cholensäure 江 Methylmagnesiumjodid を用ひて Wieland の Grignard 分解法を行ひ，3-Oxy-bis-nor-cholensäure を製して居るが, 中間體である nor-化合體は絬晶 體に取り出されて居ない。著者等は Wieland 等5) の方法に倣つて 3-Acetoxy-cholensüuremethylester (I) 飞 Phenylmagnesiumbromid を作用させて 3-Oxy-nor-cholenyl-diphenylcarbinol を製し，直ちと無水醋酸でア七チル化して Fp 172.5 の の厚い板狀晶を得を。本品は 元素分析の結果上記カルビノールのモノアセタート, $\mathrm{C}_{38} \mathrm{H}_{50} \mathrm{O}_{3}$, ル一致する故, 3-Acetoxy-norcholenyl-diphenyl-carbinol (II) 乙考へられる. 本品に水醋酸中計算量のブロームを加へて二 重結合を保護し，無水クローム酸で酸化後酸性物質中から Fp 249 250(分解下) の板狀晶を 分離した. 本品は文獻記載6) の 3-Oxy-nor-cholensäure (III) の融默に一致し, 元素分析值も 亦よく之に適合する.本品と蒲黄から得を標品とを混融したが毫も融點降下を起さなかつた。

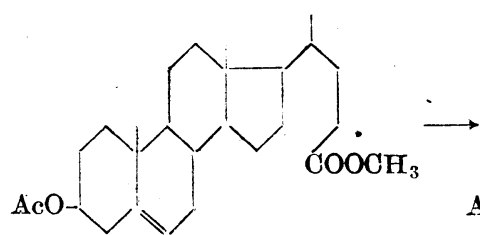

(I)

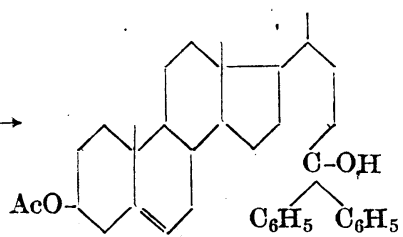

(II)

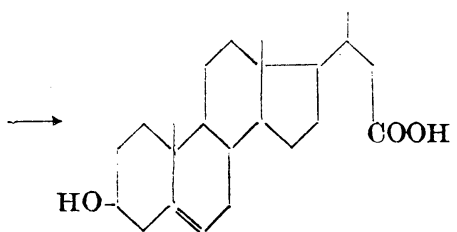

(III)

上述のやらに满黃ステリンのクロム酸酸化によつて nor一化合體が生成する事實から推して, 桑田等の謂ふ如く本品が Sitosterin と同一物質である事は明である。份賽驗の部に記したやう

3) 本誌 57, 459 [昭 12].

6) Chem. Zentr. 1937, I 4265.

$-5^{6}-$
4) 本誌 56, 433 [昭 11].

5)

Z. physiol. Chem.

161, 80 [1926]. 
そ，本ステリンの精製に際して，Liebermann 反應を現はさない 2 物質，Fp 60〜61 と $\mathrm{Fp} 75 \sim 77^{\circ}$, を分離した. 分析の結果, 前者は炭化水素, 後者は $\mathrm{C}_{28}$ 臺の高級一價アルコー 几と考入られるが，兹には唯之等 2 物質を分離した事を附記するに止める.

本研究に當り有力な指示を與一られを桑田智博士に謹謝し，元素分析を施行せられを笠原榮 三，今井晃久兩氏几深謝する.

\section{貫 驗 之 部}

薄黃ステリンの精製 桑田等の記載に從つて薄黃から抽出した粗製ステリン; Fp 59〜1080，を約 3 倍 量のアルコールーベンゾール $(1: 1)$ の混液に熱時溶解して放冷すると無晶形物質 Fp 65〜70 が析出寸る.

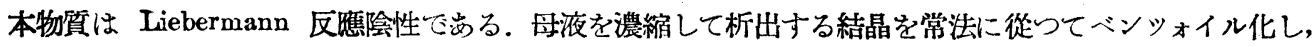
之を醋酸エステルから再結晶して Fp 147〜148 $，[\alpha]_{\mathrm{D}}=-12.41^{\circ}$ のベンツォアートを得た. 本品をアルコ

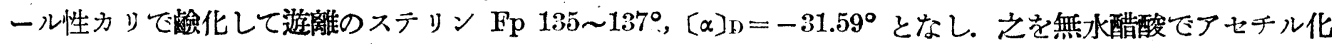

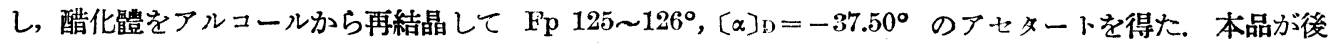
述するクロム酸酸化の原料である.

上述の Fp 65 70 を示す絮如の物質にクロマトグラフ四着分析を試みるため約 300 倍量のベンッォー ルーヘキサン $(1: 1)$ に溶解し, メルク社製の酸化アルミニウム㕌を通過させ,クロマトグラムの中央部から Fp $76 \sim 77^{\circ}$ の物質を得た.

試料 $\left(60^{\circ}, 6\right.$ 時間真空乾燥) $3.760,3.695 \mathrm{mg}: \mathrm{CO}_{2} 11.340,11.120 \mathrm{mg}, \mathrm{H}_{2} \mathrm{O} 4.730,4.580 \mathrm{mg}$.

實驗值 C 82.25, 82.08. H $14.07,13.72$.

吸着されなかつた濾液からは Fp 60〜61の䚬片狀晶を得た。

試料 $\left(60^{\circ}, 6\right.$ 時間真空乾燥) $3.489 \mathrm{mg}: \mathrm{CO}_{2} 10.845 \mathrm{mg}, \mathrm{H}_{2} \mathrm{O} 4.555 \mathrm{mg}$.

實驗值 C $84.99, \quad$ H 14.64

ステリンのチブロミド＼cjkstart前記ステリンのアセタートを水醋酸に熱時溶解し，水で泠却して之に計算量 のブロームー承醋酸溶液を滴下後暫時攪找を繼續するに結晶が析出して來る．之を滤別し，アセトンから 再結晶して Zp 124.5〜126 の結晶を得た. 分析值は Sitosterin-dibromid に一致する.

試料 $\left(90^{\circ}, 4\right.$ 時間真空乾燥) $4.040,4.090 \mathrm{mg}: \mathrm{AgBr} 2.445,2.475 \mathrm{mg}$.

$\mathrm{C}_{31} \mathrm{H}_{52} \mathrm{O}_{2} \mathrm{Br}_{2}$ 計算值 $\quad \mathrm{Br} \quad 25.94 . \quad$ 實驗值 $\quad \mathrm{Br} \quad 25.75,25.75$.

スデリンーチブロミドの酸化 上記のデブロミド $20 \mathrm{~g}$ を氷醋酸 $650 \mathrm{cc}$ に溶解 (一部不溶の䡬) し， $50^{\circ}$ の水浴中䚓拌しながら無水クローム酸一氷醋酸溶液 $\left(\mathrm{CrO}_{3} 30 \mathrm{~g}\right.$, 水 $20 \mathrm{cc}$, 水醋酸 $\left.120 \mathrm{cc}\right)$ を 3.5 時間を費し て滴下する.其の後同溫度に 6.5 時間攪汼を繼續した後メタフール $120 \mathrm{cc}$ を注加して過剩のクロム酸を 分解し, 反㕍液を隇医下に約 $100 \mathrm{cc}$ 迄濃縮する. 之に多量の水を加へエーテルと共に振量し, エーテル首 を酸, 水で順次洗涤後亞鉆末を $10 \mathrm{~g}$ 加へてェーテルを溜去し, 残渣にメタノール $300 \mathrm{cc}$, 水醋酸 $100 \mathrm{cc}$

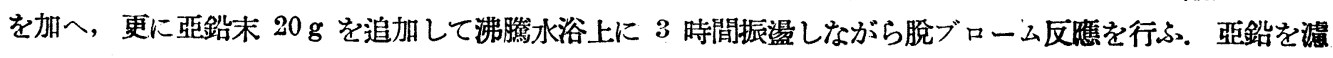

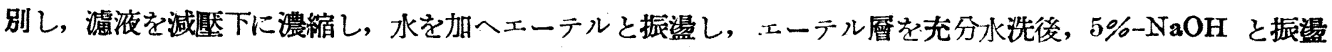
してェーテル層とアルカリ層とを分取する.

3-Oxy-nor-cholensäure の分離上述のアルカリ性水層を遠心分離機にかけて浮游する沈啭を分 別し，之を水中に㲘垂し $5 \%-\mathrm{H}_{2} \mathrm{SO}_{4}$ で允分に酸性となし，多量のェーテルで抽出し，エーテル層を水洗， 乾燥後エーテルを溜去し, 残渣を氷醋酸から再結晶して Fp $249^{\circ}$ (分解下) の板狀晶を得た. 本品はヂギ 


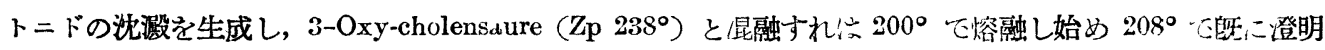
な熔融狀を呈する.

試料 $\left(100^{\circ}, 6\right.$ 時閒賽空乾燥) $4.020 \mathrm{mg}$ : $\mathrm{CO}_{2} 11.320 \mathrm{mg}, \mathrm{H}_{2} \mathrm{O} 3.605 \mathrm{mg}$.
$\mathrm{C}_{23} \mathrm{H}_{36} \mathrm{O}_{3}$ 計算値
C 76.60
$\mathrm{H} \quad 10.07$
賽驗值
C 76.80
H 100 ?

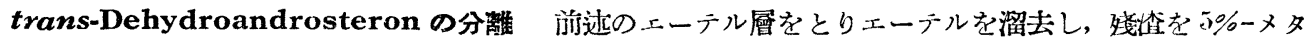

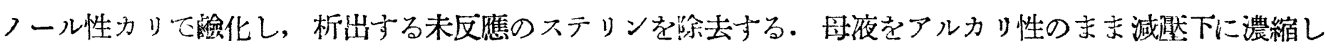

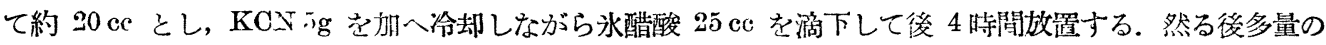

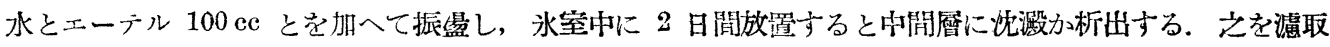

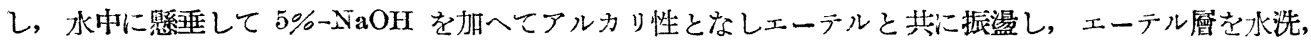
乾燥後エーテルを溜去し，残渣をへキサンから 再結晶すれは Fp 149-141ㅇ の板狀晶か得られる. 本品と Cholesterin から酸化によつて得られた trans-Dehydroandrosteron と混融したか毫も融點降下を起さなかつ た.

試料 $\left(80^{\circ}, 6\right.$ 時間稘空乾燥) $3.710 \mathrm{mg}$ : $\mathrm{CO}_{2} 10.720 \mathrm{mg}, \mathrm{H}_{2} \mathrm{O} 3.190 \mathrm{mg}$
$\mathrm{C}_{19} \mathrm{H}_{28} \mathrm{O}_{2}$ 計算值
C $\quad 79.07$
H 9.75
實驗值
C 78.80
H 9.62

3-Acetoxy-nor-cholenyl-diphenyl-carbinol（II）の製造三到コルベン內に磁庞した $\mathrm{Mg}$ 片 $5 \mathrm{~g}$ ，轮燥ブロムベンゾール $35 \mathrm{~g}$, 無水エーテル $150 \mathrm{cc}$ と少量のヨードとを容れ，防濕しながら覴找して反 應せしめた後水浴上に暫時加溫して Mg を完全に溶解せしめる. 之に 3-Acetoxy-cholensiure-methylester （I） $6 \mathrm{~g}$ を無水ベンゾール $200 \mathrm{cc}$ に溶かしたものを 40 分を費して加へ，向沸膫下に 3 洔間撜拌を繼續し

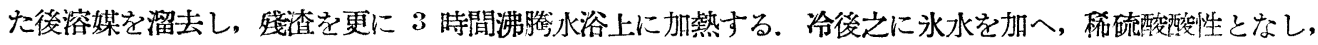
エーテルて振蕰する. エーテル層を水洗後エーテルを溜去し, 残渣を水蒸氣蒸溜に附してヂフェニルを除去

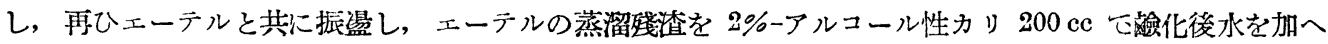
て稀硫较酸性となし，再で水蒸氣蒸溜に附して完全にデフェニルを除去する．然る後蒸溜殘查をエーテルと 共に振盪し, エーテル層を水, アルカリ漗夜, 水で逐次洗滌乾燥後エーテルを溜去する. 此處に得た油狀 物質に無水醋酸 $30 \mathrm{cc}$ を加へ 2 時間意沸後減壓下に醋酸を溜去し, 残渣に石油エーデルを加へ万と結晶性 物質が析出する. 之をアセトンから再結晶して厚い板狀晶 Fp 172〜172 5゚を得だ

試料 (90 100 4 時間真空乾燥) $3.210 \mathrm{mg}: \mathrm{CO}_{2} 9.730 \mathrm{mg}, \mathrm{H}_{2} \mathrm{O} 2.490 \mathrm{mg}$
$\mathrm{C}_{38} \mathrm{H}_{50} \mathrm{O}_{3}$ 計算値
C $\quad 82.25$
H 9.09
實驗嗢
C 82.67
H 8.68

3-Oxy-nor-cholensäure (III) の製造＼cjkstart前述のカルビノール（II） $3.76 \mathrm{~g}$ を精製水酷酸 $250 \mathrm{cc}$ と ベンゾール $50 \mathrm{cc}$ とに溶解し, 之に N-ブロム氷酷酸溶夜 $13.54 \mathrm{cc}$ ( $1 \mathrm{Mol}$ ) を滴下し, 1 時聞放置後溫度 を $50^{\circ}$ に保ち㩭拌しながら無水クローム酸水醋酸溶液 $\left(\mathrm{CrO}_{3} 4 \mathrm{~g}\right.$ 水 $4 \mathrm{cc}$, 水醋酸 $\left.40 \mathrm{cc}\right)$ を 1 時間費し て加へ，同溫度で更に 12 時間覮拌を継續する. 冷後之に水を加へ析出する物質をエーテルにとり，エー テル愿を水洗, 乾燥後 $\mathrm{Zn}$ 末 $15 \mathrm{~g}$ を加へてエーテルを溜去 (隇壓下にベンゾールも溜去する) し, 残渣に

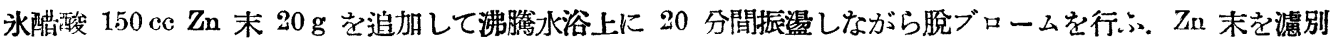

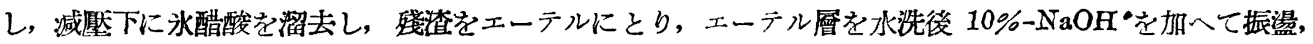
放置するとアルカリ㒶に沈澱が析出する. 之を濾取して水中に㲘垂し, 稀硫酸酸性となし, エーラ゙ルと共

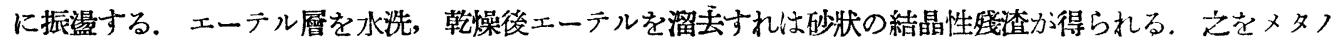
ールから再結晶して Fp 249 250 (分解下) の板狀晶を得た. 本品と 3-Oxy-cholensdure と提融すれば $200^{\circ}$ から $207^{\circ}$ て澄明に愹融する. 前に薄黃ステリンの酸化によつて得た Fp $249^{\circ}$ の物質と湜融してす 毫も蜝點降下を起さない。

試料 $\left(100^{\circ}, 6\right.$ 時間真空乾燥) $4.045 \mathrm{mg}$ : $\mathrm{CO}_{2} 11.320 \mathrm{mg}, \mathrm{H}_{2} \mathrm{O} 3.600 \mathrm{mg}$.

$$
\mathrm{C}_{23} \mathrm{H}_{26} \mathrm{O}_{3} \text { 計算值 } \quad \mathrm{C} \quad 76.60, \quad \mathrm{H} \quad 10.07 \text { 實驗值 } \quad \mathrm{C} \quad 76.32, \mathrm{H9.96} \text {. }
$$

